\title{
Effect of Peritoneal Lavage with Coconut Water in Healing of Colon Anastomosis in Rat Abdominal Sepsis Model
}

\author{
Efeito da Lavagem Peritoneal com Água de Coco na Cicatrização de \\ Anastomoses do Cólon em Modelo de Sepse Abdominal em Ratos
}

Bárbara Bruna de Sousa Pires ${ }^{1}$, Ítalo Medeiros Azevedo², Marília Daniela Ferreira de Carvalho Moreira ${ }^{2}$, Lívia Medeiros Soares Celani ${ }^{3}$, Aldo Cunha Medeiros ${ }^{4}$

1. Graduate student, Medical School, Federal University of Rio Grande do Norte (UFRN), Natal-RN, Brazil.

2. Fellow PhD degree, Postgraduate Program in Health Sciences, Federal University of Rio Grande do Norte (UFRN), Natal-RN, Brazil.

3. MD, University Hospital Onofre Lopes, UFRN, Natal-RN, Brazil.

4. Full Professor, Chairman, Nucleus of Experimental Surgery, UFRN, Natal-RN, Brazil.

Study performed at Department of Surgery, Federal University of Rio Grande do Norte (UFRN), Brazil.

Financial support: none.

Conflict of interest: None.

Correspondence address: Department of Surgery, Federal University of Rio Grande do Norte, at Ave. Nilo Peçanha 620, Natal, RN, Brazil. E-mail: cirurgex.ufrn@gmail.com

Submitted: June 10, 2017. Accepted, after review: July 22, 2017.

\section{ABSTRACT}

Purpose: The objective of this study was to evaluate the efficacy of peritoneal lavage with coconut water in the healing of colonic anastomoses in a model of abdominal sepsis in rats. Methods: Twelve Wistar rats were used. The animals were randomly selected and distributed in 2 groups, with six rats each. Group 1: rats with sepsis + peritoneal lavage with $0.9 \%$ saline solution and Group 2: rats with sepsis + peritoneal lavage with coconut water. Induction of abdominal sepsis was performed through the exteriorization of the cecum and ligature. After ligation, 4 perforations and gentle pressure were made in the cecum, allowing the small amount of stool to escape. The cecum was then replaced in the abdominal cavity and the abdominal incision sutured. Six hours after induction of sepsis, under anesthesia in all animals, $2 \mathrm{~cm}$ of colon resection and anastomosis were performed. The peritoneal lavage therapy was repeated 3 times, each wash with $5 \mathrm{ml}$ of solution, which remained in the peritoneal cavity for 1 minute and then removed with sterile dry gauze. Coconut water was obtained from Cocus nucifera $L$ specimens, with sterile technique for administration to the animals. Results: In group 2 the bursting pressure of anastomosis was $196.3 \pm 17.47 \mathrm{mmHg}$, significantly higher $(p=0.001)$ than in 
Effect of Peritoneal Lavage with Coconut Water in Healing of Colon Anastomosis in Rat Abdominal Sepsis Model

Pires BBS, et al

the saline group, $(152.8 \pm 12.31 \mathrm{~mm} / \mathrm{Hg})$. The peritoneal lavage group with coconut water presented histological scores with a significantly $(p<0.001)$ lower inflammatory process (score 14.8 \pm 3.13 ) compared to the saline group (score $31.7 \pm 4.92$ ). The count of colony forming units (CFU) in the peritoneal fluid was significantly lower $(p=0.001)$ in the coconut water group (16.0 $\pm 7.32 \mathrm{CFU})$ than in the saline group (83.5 $\pm 8.62 \mathrm{CFU})$. Conclusion: The treatment of abdominal sepsis with peritoneal lavage using coconut water positively afluenced the healing of colon anastomosis in rats. It favored the bursting pressure, the reduction of inflammatory process, and bacterial colonization.

Key words: Sepsis. Coconut. Water. Abdomen. Anastomosis. Colon. Healing. Rats.

\section{RESUMO}

Objetivo: O objetivo deste estudo foi avaliar a eficácia da lavagem peritoneal com água de coco na cicatrização de anastomoses colônicas em um modelo de sepse abdominal em ratos, em comparação com solução salina a 0,9\%. Métodos: Doze ratos Wistar foram utilizados. Os animais foram selecionados aleatoriamente e distribuídos em 2 grupos, com seis ratos cada: Grupo 1: ratos com sepse + lavagem peritoneal com solução salina a $0,9 \%$ e grupo 2: ratos com sepse + lavagem peritoneal com água de coco. $A$ indução da sepse abdominal foi realizada através da ligadura do ceco e 4 perfurações, seguidas de pressão suave no ceco, permitindo saída de pequena quantidade de fezes. 0 ceco foi introduzido na cavidade abdominal e a incisão abdominal suturada. Seis horas após, sob anestesia foi realizada resseç̧ão de $2 \mathrm{~cm}$ do cólon e anastomose. A terapia de lavagem peritoneal foi repetida 3 vezes, cada lavagem com $5 \mathrm{ml}$ de solução, que permaneceu na cavidade peritoneal durante 1 minuto e depois removida com gaze seca estéril. A água de coco foi obtida a partir de amostras de Cocus nucifera $L$, com técnica estéril para administração na cavidade peritoneal. Resultados: No grupo 2, a pressão de ruptura das anastomoses foi de $196,3 \pm 17,47 \mathrm{mmHg}$, significativamente $(p=0,001)$ maior do que no grupo salina $(152,8 \pm 12,31 \mathrm{mmHg})$. O grupo lavagem peritoneal com água de coco apresentou escores histológicos com processo inflamatório significativamente $9 p<0,001$ ) menor (escore $14,8 \pm 3,13$ ) em comparação com o grupo salino (escore $31,7 \pm 4,92$ ). A contagem de unidades formadoras de colônias (UFC) no líquido peritoneal foi significativamente menor $(p<0,001)$ no grupo água de coco $(16,0 \pm 7,32$ UFC) do que no grupo salina $(83,5 \pm 8,62$ UFC). Conclusão: $O$ tratamento da sepse abdominal com lavagem peritoneal com água no coco influenciou positivamente a cicatrização da anastomose do cólon em ratos. Favoreceu a pressão de ruptura das anastomoses, a redução do processo inflamatório e a colonização bacteriana.

Descritores: Sepse. Abdome. Anastomose. Cólon. Cicatrização. Ratos. 
Effect of Peritoneal Lavage with Coconut Water in Healing of Colon Anastomosis in Rat Abdominal Sepsis Model

Pires BBS, et al

\section{INTRODUCTION}

Abdominal sepsis can be initiated by the direct action of microorganisms that colonize the intestine, especially the colon ${ }^{1}$. Colon perforation is one of the main causes of contamination, producing severe peritonitis. The most frequent agents by the infectious process are the gram-negative bacteria, Escherichia coli, Proteus sp., Klebsiella sp. And Enterobacter sp., Gram-positive, Enterococcus faecalis, and anaerobic, Peptostreptococus SP, Bacteroides fragilis and Fusobacterium sp. The classic treatment is surgical intervention for the removal of aggressive agents, control of infectious focus by washing the abdominal cavity with drainage, associated with antibiotic therapy, to prevent and treat recurrent infection, and peritoneal lavage techniques using laparotomy or laparoscopy ${ }^{2}$.

Peritonitis is one of the most important etiology of sepsis and death in surgical patients and intensive care units, and its study is of great clinical relevance ${ }^{1}$. Additionally, due in part to increasing bacterial resistance caused by the indiscriminate use of antibiotics, studies have sought new peritoneal lavage solutions for the treatment of peritonitis. The use of anesthetic solution composed of $0.3 \%$ ropivacaine in the treatment of induced fecal peritonitis in rats showed a higher survival rate, comparing to $0.9 \%$ saline solution because of its anti-inflammatory and anti-bacterial properties ${ }^{1}$. Other previous studies have demonstrated a reduction in fecal peritonitis in rats treated with lavage containing lidocaine and bupivacaine, These local anesthetics influenced in several stages of the inflammatory cascade, mainly in the reduction of leukocyte adhesion to endothelium ${ }^{1,2}$.

A study on the use of direct peritoneal resuscitation with solution for peritoneal dialysis at $2.5 \%$ glucose in patients submitted to surgery for damage control revealed that tehy showed improvement in tissue perfusion3. This finding is important because in surgery for damage control in the cases of pancreatitis, viscera perforation, intestinal obstruction and enterocolic ischemia there is the possibility of progressive vasoconstriction due to abnormal blood flow, which would lead to tissue hypoxia, 
Effect of Peritoneal Lavage with Coconut Water in Healing of Colon Anastomosis in Rat Abdominal Sepsis Model

Pires BBS, et al

irreversible cellular damage, multiple organ failure and death. The possibility of reversion of this condition has been studied using peritoneal lavage fluid for peritoneal dialysis ${ }^{3}$.

A systematic review showed that laparoscopic peritoneal lavage is safe and effective, with low mortality, morbidity and no need for a stoma, which reduces hospital costs and patient stress ${ }^{4}$. It was observed that abdominal and systemic sepsis were successfully controlled through laparoscopic lavage in $97.5 \%$ of the patients, with a minimum of mortality (1.7\%), morbidity (10.4\%) and need for enteric stoma $(1.7 \%)$.

However anastomosis dehiscence is a serious complication in colorectal surgeries and should be prevented and treated early. The reduction of dehiscence as well as the healing process of colon anastomosis is due to factors involving both surgical techniques and a complex interaction of growth factors and collagen synthesis, inflammation, fibroplasia and collagen maturation ${ }^{5}$.

Healing is a complex process influenced by a number of factors, including the general condition of the patient, blood supply and tissue oxygenation, local vascular quality, blood volume, surgical technique and anastomosis site ${ }^{6}$.

Peritoneal lavage is a procedure that dilutes enzymes which inactivate antimicrobials and digests tissues, removes toxic substances derived from bacteria or released by cell destruction, and removes foreign material such as feces, gastrointestinal secretion, urine, bile, blood, pus and fibrin${ }^{7}$. Ideally, the liquids used in the peritoneal lavage should not induce adverse reactions. For this reason, it is important that the composition is as close as possible to the composition of the extracellular and intracellular body fluids. The saline solution is the most commonly used fluid to wash the peritoneal cavity, restoring normal metabolism, and allowing the correction of acid-base and hydroelectrolytic imbalances ${ }^{7}$.

In this context, coconut water is a fluid that shows relevant chemical and biological characteristics, and its use for peritoneal lavage may be quite promising ${ }^{8}$. It has been reported the use of coconut water, in small amounts and in a short period of time, for intravenous hydration, evidencing success and improvement in the physiological conditions of the patients and showing no antigenic effects and systemic reactions ${ }^{9}$. The 
Effect of Peritoneal Lavage with Coconut Water in Healing of Colon Anastomosis in Rat Abdominal Sepsis Model

Pires BBS, et al

composition of the coconut water resembles the density and concentration of phosphate and calcium ions that in part mimics the intracellular and extracellular fluids ${ }^{9}$. Coconut water is also rich in essential amino acids including lysine, leucine, cystine, phenylalanine, histidine, and tryptophan. In addition, like saline, it has no effect on hemostasis ${ }^{8}$. Therefore, studies about the effects of coconut water on healing anastomosis are scarce. These analyzes also show some differences in the composition of coconut water and human blood plasma, since it presents an acidic $\mathrm{pH}$ (5.6), hypotonicity, a higher concentration of potassium, magnesium and glucose, and a lower concentration of sodium $^{10}$.

The objective of our study was to evaluate the efficacy of peritoneal lavage with coconut water in the healing of colonic anastomoses in a model of abdominal sepsis in rats compared to the use of $0.9 \%$ saline solution.

\section{METHODS}

Wistar rats (Rattus norgegicus) provided by the Health Sciences Center of the Federal University of Rio Grande do Norte (UFRN) were used. This protocol was approved by the institutional Ethics Committee on Animal Use (CEUA/HUOL - Protocol 01/16). The care in the use of the animals followed the rules of the Brazilian Legislation for the scientific use of animals (Law $n$ ㅇ 11.794/2008). The study was performed at the Nucleus of Experimental Surgery-UFRN.

\section{Experimental design}

The animals were randomly selected and distributed in 2 groups, with six rats each. Group 1: rats with sepsis + peritoneal lavage with $0.9 \%$ saline solution. Group 2: rats with sepsis + peritoneal lavage with coconut water. The rats were kept in individual polypropylene cages with light-dark $12 \mathrm{~h}$ cycles. The animals stayed for 7 days at the Nucleus of Experimental Surgery-UFRN for acclimatization, with ad libitum access to water and food for rats (Presence $\left.{ }^{\circledR}\right)$.

\section{Induction of abdominal sepsis}


Effect of Peritoneal Lavage with Coconut Water in Healing of Colon Anastomosis in Rat Abdominal Sepsis Model

Pires BBS, et al

Following anesthesia with xylazine at a dose of $10 \mathrm{mg} / \mathrm{kg}$ and ketamine $70 \mathrm{mg} / \mathrm{kg}$ i.p., depilation of the abdominal wall was performed. The rats were fixed in operation table with adhesive tapes in dorsal decubitus and abdominal antisepsis with $70 \%$ alcohol was done. Under asseptic trchnique, a median laparotomy of $4 \mathrm{~cm}$ exposed the cécum. A cécum ligation and puncture (CLP) was performed. Breafly, he cecum was ligated with 2-0 cotton suture and 4 perforations with needle $n=25 F$ were done. A soft pressure in the cecum, allowed a small amount of feces to exit. The cecum was then be replaced in the abdominal cavity, the abdominal incision were sutured with 4-0 nylon sutures and the animals returned to the polypropylene cages. The animals of the sham group were submitted only to laparotomy, soft manipulation of the cecum and abdominal wall suture in 2 planes.

\section{Colon resection and anastomosis}

Six hours after the sepsis induction, under anestesia, a resection of $2 \mathrm{~cm}$ of the colon was performed at $5 \mathrm{~cm}$ of the peritoneal reflection. The intestinal continuity was restored with end-to-end anastomosis in a single plane with interupted sutures, using polypropylene 6-0, using a surgical microscope DFV (São Paulo, Brazil), 10x magnification. After surgery, postoperative pain was controlled with analgesia (meperidine i.m. at a dose of $10 \mathrm{mg} / \mathrm{kg}$, a daily dose in the first 3 days). Animals receive only water in the first 24 hours postoperatively, followed by a solid diet until euthanasia. They were weighed before the operation and in the immediate moment before the euthanasia that take place on the 7th postoperative day.

\section{Peritoneal lavage}

The peritoneal lavage was repeated 3 times, each wash with $5 \mathrm{ml}$ of solution, which was remained in the peritoneal cavity for 1 minute, and then was withdrawn with sterile dry gauze. The solutions were heated to $36.5^{\circ} \mathrm{C}$ just prior to use. In 6 animals of the sepsis group, the abdominal cavity was washed with coconut water; In the remaining 6 animals, washing was done with $0.9 \%$ saline solution. The fluid from the first wash was collected for microbiological analysis. 
Effect of Peritoneal Lavage with Coconut Water in Healing of Colon Anastomosis in Rat Abdominal Sepsis Model

Pires BBS, et al

\section{Coconut water collection and manipulation}

The coconut water was obtained from specimens of Cocos nucifera $L$ of 6 months, period from the inflorescence to the fruit harvest. With sterile technique, water was withdrawn from the coconut immediately prior to administration to the animals. The $\mathrm{pH}$ of the coconut water was previously adjusted to 7.4 using $10 \%$ sodium bicarbonate, the liquid being filtered through a sterile filter before use in the peritoneal lavage. The $0.9 \%$ saline solution was from B. Braun, Rio de Janeiro, Brazil. After the treatments described above the animals were observed for 7 days, when they were submitted to euthanasia with anesthetic overdose (Tiopental $100 \mathrm{mg} / \mathrm{kg}$ ) i.p., and the colon anastomoses were evaluated.

\section{Microbiological study}

The fluid from the first wash was collected for bacteriological study. A calibrated bacteriological loop $(1 \mu l)$ was introduced into the sample, the liquid was distributed on the surface of the culture medium Cromoclin US (Paraná, Brazil) and incubated for $24 \mathrm{~h}$ at 35으. After bacterial growth, colonies identified by specific colors were counted. The number of colonies was multiplied by the dilution factor of the loop to obtain the number of Colony Forming Units per $\mathrm{ml}$ of sample (CFU/ml). Identification of the bacterial colonies was done by color and a Rugai Kit with lysine was used to identify the respective strains. Quantification was done in CFU/ml, transformed in logarithm.

\section{Assessment of anastomosis resistance}

The colon anastomosis zone was submitted to the pressure resistance test on the 7th postoperative day, proceeding as follows: after anesthesia, a new laparotomy was performed. The colon was sectioned proximally and distally to the anastomosis zone. Polyethylene $n=6 F$ catheter was inserted into its proximal lumen, fixed therein with $n=00$ cotton suture; a second catheter was inserted into the distal end of the loop, also tied with $\mathrm{n} 000$ cotton. This is hermetically closed connection was attached a digital pressure recorder. The peritoneal cavity was filled with saline solution, keeping the colonic anastomosis zone immersed in saline. $\mathrm{O}_{2}$ was then infused in a continuous stream of 0.5 
Effect of Peritoneal Lavage with Coconut Water in Healing of Colon Anastomosis in Rat Abdominal Sepsis Model

Pires BBS, et al

liter per minute. The maximum rupture pressure of the anastomosis was considered at the moment of bubbling of air in the aqueous solution.

\section{Evaluation of the anastomosis healing}

A sample containing the colon anastomosis was fixed in $10 \%$ formalin and included in paraffin. $5 \mu \mathrm{m}$ sections were stained with hematoxylin and eosin and analyzed in optical microscopy by an experienced pathologist, without previous knowledge of the respective groups. Tissue response was assessed in scores according to the method used by Storch et $\mathrm{al}^{16}$. In this system, the tissue samples were examined microscopically taking into account the parameters with the respective weights: neutrophils (6), macrophages (1), giant cells (2), edema (2), lymphocytes (2), cell density (3) and fibroblasts (1), which were quantified on a scale of 1 to 10 , with 10 representing the highest possible concentration of cells. These data were weighted to emphasize the significance of the inflammatory response, attributing the highest value to neutrophils. The sum of the weighted values generated an aggregate score of the tissue response for each animal.

\section{Statistics}

Statistical evaluation was performed using SPSS $^{\circledR}$ software 21. Initially, the normality was evaluated through the Shapiro Wilk and Kolmogorov-Smirnov test. To test the hypothesis of difference between the two groups, Student's t-test was used for independent samples. The significance level was $5 \%$.

\section{RESULTS}

Table 1 shows the results of the bursting pressure of colon anastomosis, histological scores and bacerial colony forming units $/ \mathrm{mL}$ for groups. The coconut water group rats presented significantly higher bursting pressure $(p=0.001)$ in the anastomosis

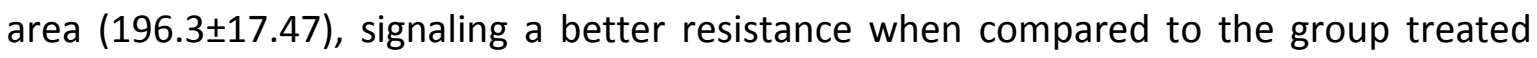

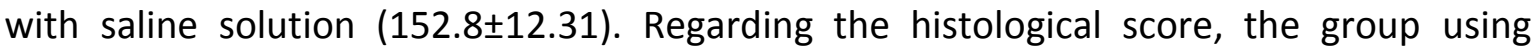

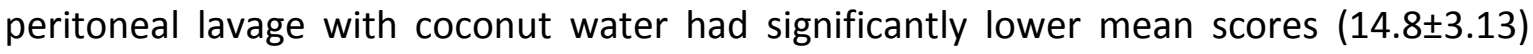
than in the treated rats with saline peritoneal lavage $(31.7 \pm 4,92)$, which translated into a 
Effect of Peritoneal Lavage with Coconut Water in Healing of Colon Anastomosis in Rat Abdominal Sepsis Model

Pires BBS, et al

smaller inflammatory process $(p<0.001)$. We observed significant reduction of neutrophils, macrophages, giant cells, edema, lymphocytes, cell density and fibroblasts. In the analysis of the $\mathrm{cfu} / \mathrm{ml}$ count of bacteria present in the peritoneal fluid, a significant reduction $(p=0.001)$ was also observed in group rats treated with coconut water, compared to the saline group. (16.0 \pm 7.32 and $83.5 \pm 8.62$, respectively).

Table 1 - Results of descriptive statistics of anastomosis bursting pressure, histological score and colony forming units count $(\mathrm{cfu} / \mathrm{ml})$ and respective inferential statistical test.

\begin{tabular}{|c|c|c|c|}
\hline \multirow[b]{2}{*}{ Variables } & \multicolumn{2}{|c|}{ Groups } & \multirow[b]{2}{*}{$p$-value } \\
\hline & Coconut water & Saline $0.9 \%$ & \\
\hline Bursting pressure (mmHg) & $196,3 \pm 17,47$ & $152,8 \pm 12,31$ & 0,001 \\
\hline Histogic score & $14,8 \pm 3,13$ & $31,7 \pm 4,92$ & $<0,001$ \\
\hline $\begin{array}{l}\text { Colony forming units } \\
(\mathrm{cfu} / \mathrm{ml})\end{array}$ & $16,0 \pm 7,32$ & $83,5 \pm 8,62$ & 0,001 \\
\hline
\end{tabular}

Mean \pm standard deviation; Student t test

Figure 1 shows a Box-plot graph illustrating the analysis of anastomosis bursting pressure in each group. It is observed a significant diference between the data, since there is no intersection between the groups in the first quartile, third quartile or median. Group peritoneal lavage with coconut water presented higher anastomosis bursting pressure than saline group. 
Effect of Peritoneal Lavage with Coconut Water in Healing of Colon Anastomosis in Rat Abdominal Sepsis Model

Pires BBS, et al

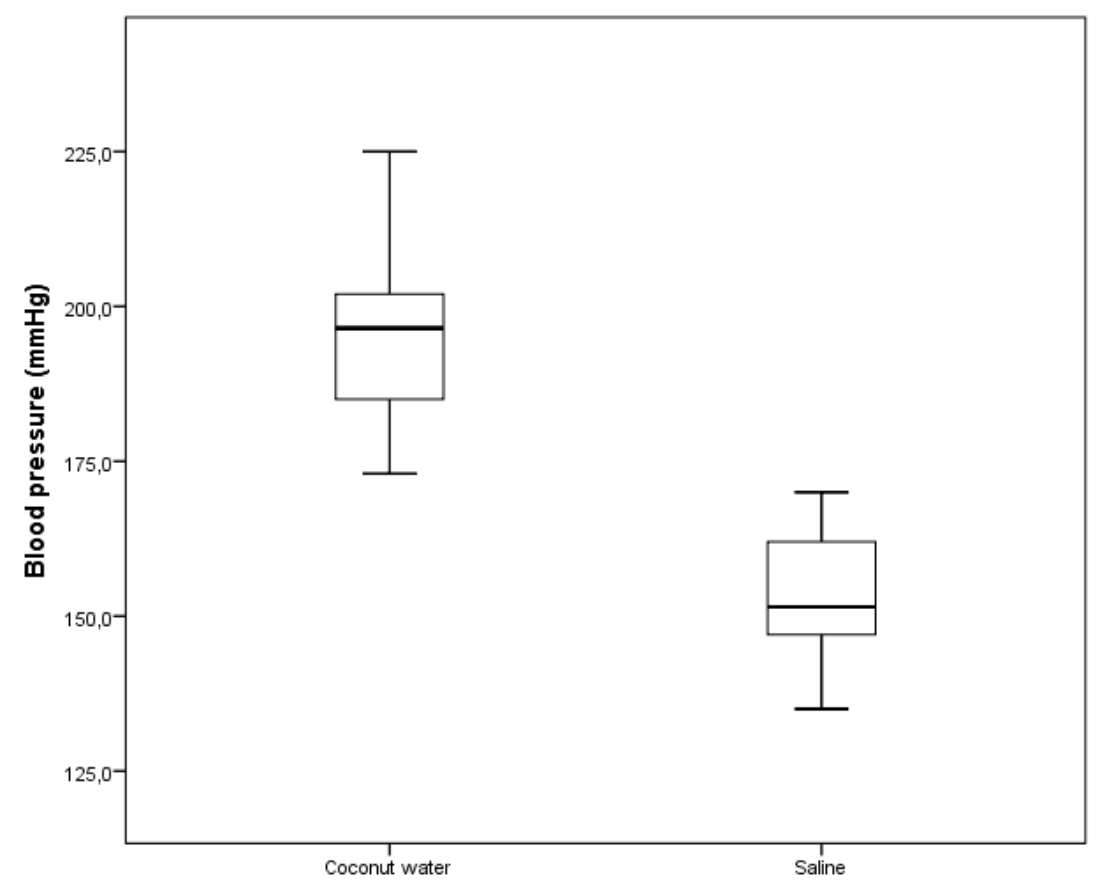

Figure 1 - Box-plot representing the colon anastomosis bursting pressure.

Figure 2 shows a Box-plot graph for the histological scores of colon anastomosis áreas. There is a significant difference comparing the scores of the two groups. For the peritoneal lavage group with coconut water, a median of 15 was observed, compared to the saline group with a median of 30 , confirming a lower inflammatory process and tissue damage in the area of anastomosis of rats submitted to peritoneal lavage with coconut water. 
Effect of Peritoneal Lavage with Coconut Water in Healing of Colon Anastomosis in Rat Abdominal Sepsis Model

Pires BBS, et al

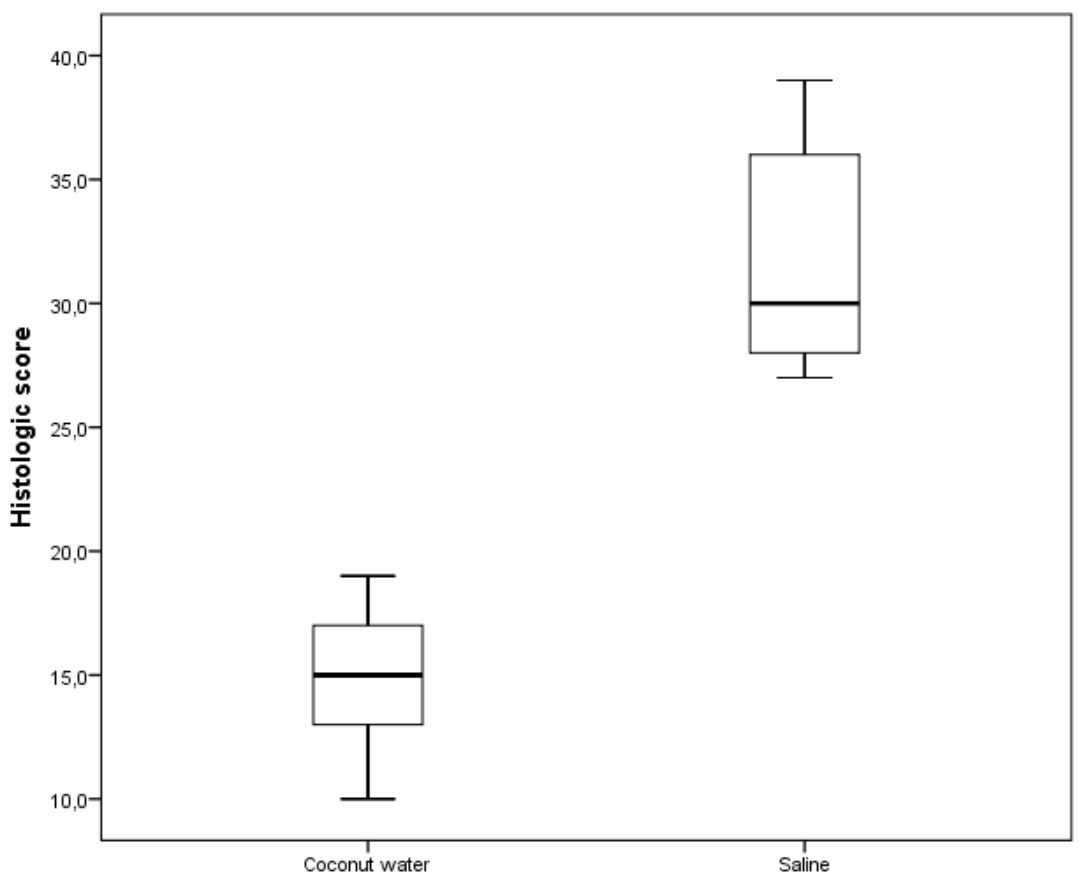

Figure 2 - Box-plot related to histologic scores of colon anastomosis.

Figure 3 shows Box-plot graph for bacterial $\mathrm{cfu} / \mathrm{mL}$ on the coconut water and saline solution groups. It is observed an intersection between the first quartile, third quartile or median of the groups, showing how much the number of bacterial $\mathrm{cfu} / \mathrm{mL}$ in the coconut water groups was significantly lower when compared to the saline group. 
Effect of Peritoneal Lavage with Coconut Water in Healing of Colon Anastomosis in Rat Abdominal Sepsis Model

Pires BBS, et al

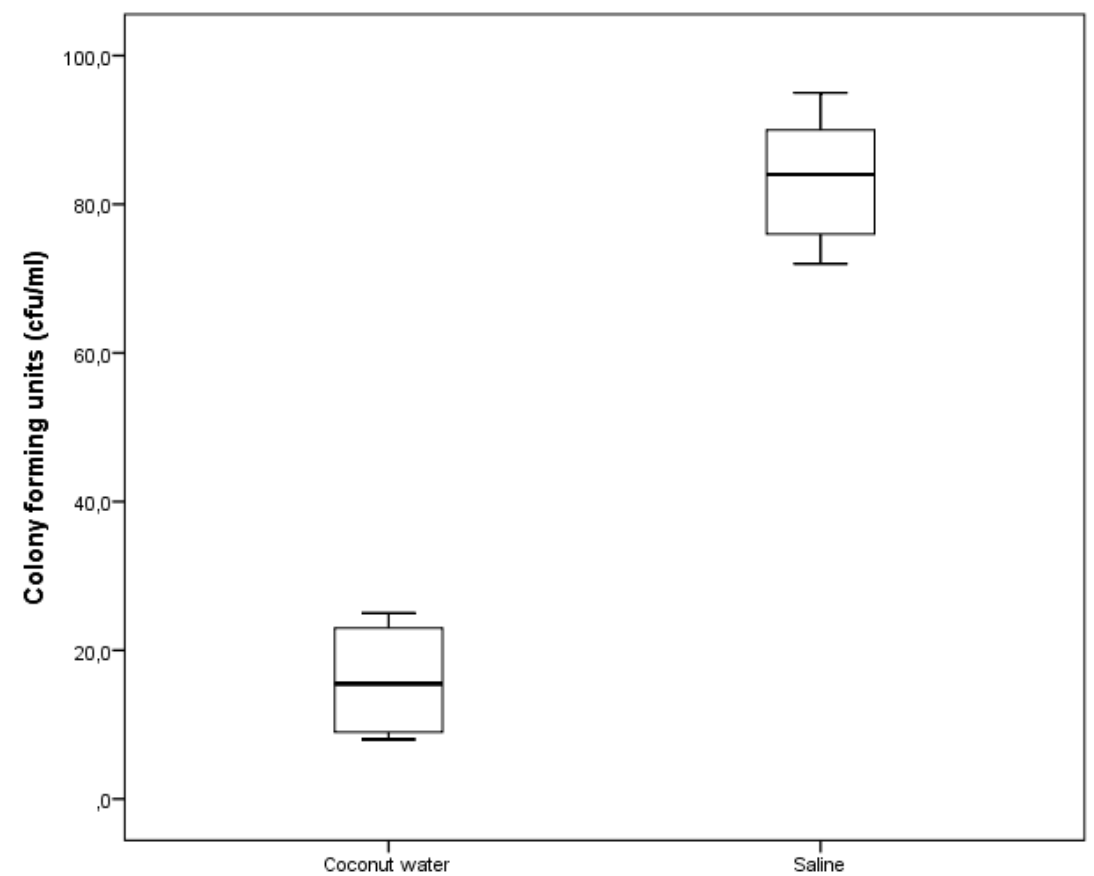

Figure 3 - Box-plot related to baterial colony forming units $/ \mathrm{mL}$ in each group.

Figure 4 shows representative images of the colonic anastomosis of septic group rats submitted to peritoneal lavage with coconut water. The integrity of the intestinal mucosa epithelium, cell disruption and fibrin deposition are better when compared to figure 5 .
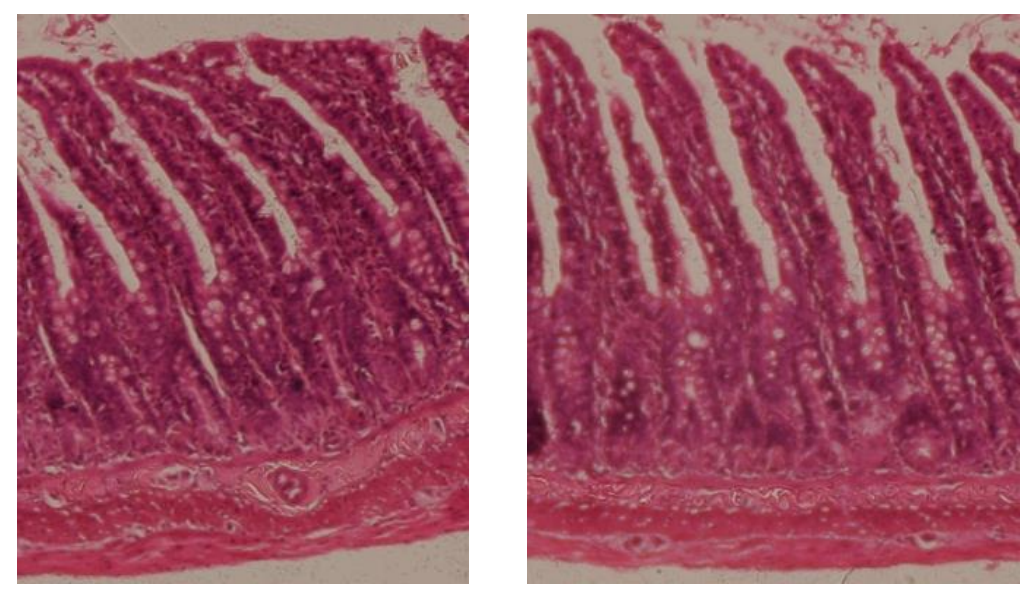

Figure 4 - Histology of colon anastomosis - Group sepsis + coconut water. $\mathrm{HE}, 200 \mathrm{x}$

Figure 5 shows representative images of histological sections of the colon anastomosis of 2 animals with sepsis in which peritoneal lavage with saline solution was performed. We observed that in this group there was a greater disruption of intestinal 
Effect of Peritoneal Lavage with Coconut Water in Healing of Colon Anastomosis in Rat Abdominal Sepsis Model

Pires BBS, et al

mucosa epithelium, greater damage to villi and fibrin deposition, when compared to figure 4 .
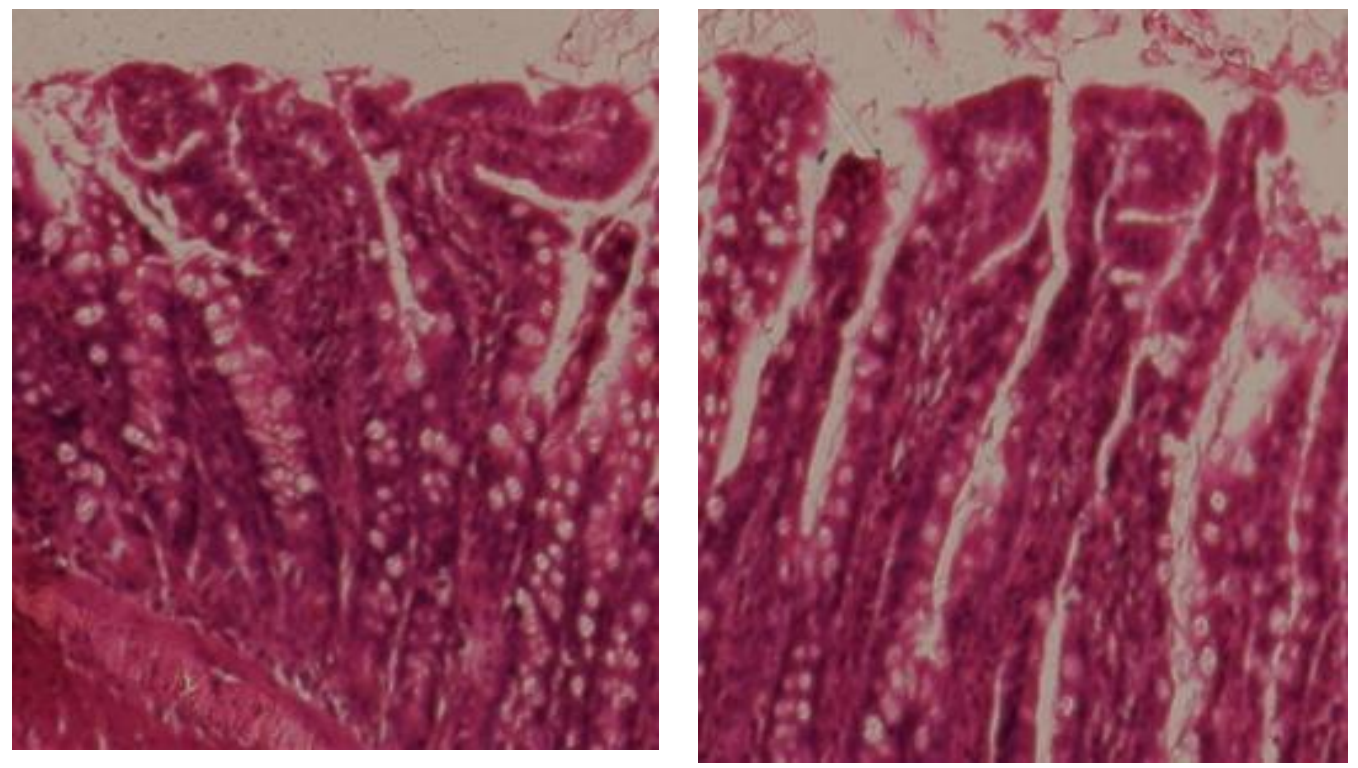

Figure 5 - Representative images of colon anastomosis histology - Group sepsis + saline. HE, $200 x$

\section{DISCUSSION}

Previous studies confirm the importance of peritoneal lavage in the prognosis of peritonitis ${ }^{2,4,7,11}$. One of the most fearsome complications of peritonitis is sepsis. There are varying degrees of sepsis associated with peritonitis that depend on the initial treatment, from the time to the beginning of therapy, on the aggressiveness of the pathogens, on the bacterial load, on the extent and duration of the contamination ${ }^{11,12}$. Several solution fluids have already been used in peritoneal lavage in an attempt to control peritonitis. There are reports of the use of saline solutions, acidic pepsin, carbolic acid, mercury chloride, salicylic acid, ethacryidine, water, camphor oil, camphor oil with ether, sodium hypochlorite, hypertonic glucose, alcohol, ether, prednisolone ${ }^{13}$, povidoneiodine, chlorhexidine, hydrogen peroxide and antibiotics ${ }^{11}$. The peritoneal lavage with saline solution has been used for many years and has shown favorable results ${ }^{7}$. Vigorous washing removes septic substances, blood, fibrin clots, dilutes the residual bacteria and helps to expand the intravascular volume. However, peritoneal lavage can cause 
Effect of Peritoneal Lavage with Coconut Water in Healing of Colon Anastomosis in Rat Abdominal Sepsis Model

Pires BBS, et al

disadvantages by impairing some local defense mechanisms by diluting opsonins, removing macrophages, lymphocytes and polymorphonuclear cells, and possibly contaminating clean areas in cases of localized peritonitis, which, according to some authors, lavage is not the best management ${ }^{11,12}$.

In contrast, it is believed that the addition of hypertonic substance within the peritoneal cavity may lead to hypotension and even hypovolemic shock due to the deviation of water from the intravascular space into the peritoneal cavity. Cell damage due to hyperosmolarity is questionable ${ }^{11,12}$. However, studies question such damages, showing that the cells are protected from high sugar concentrations by intercommunication with other cells of the same organism, allowing the exchange of water between them ${ }^{11}$. Other works have shown beneficial effects of the use of sucrose in wound healing, acting not only as a harmful agent of bacteria by mechanisms of hyperosmolarity, but also with antibacterial action and modulation of the inflammatory response $^{11}$.

Coconut water presents in its composition electrolytes and sugars that give coconut various uses, including the conservation of tissues ${ }^{14}$. Because it contains sugar, amino acids, antioxidants and other components, coconut water may be a good alternative for peritoneal lavage. It is likely that these qualities may have worked favorably in peritoneal lavage in our experimental model. In addition, it shold have been involved in the mechanical removal of microorganisms, with some antimicrobial effect and modulation of the inflammatory response, due to its diverse composition ${ }^{8-10,15}$.

We observed that peritoneal lavage with coconut water had several advantages in favor of the healing process. Our study showed increased anastomosis bursting pressure on the group with coconut water peritoneal lavage, which allowed that in this group the risk of dehiscence was lower. In addition, changes in intestinal mucosa were lower in the group submitted to peritoneal lavage with coconut water, confirmed by histopathological analysis that presented less damage to the intestinal epithelium than in saline peritoneal lavage. Another aspect of great relevance was the reduction of bacterial colonies in peritoneal fluid in the coconut water lavage group when compared to the 
Effect of Peritoneal Lavage with Coconut Water in Healing of Colon Anastomosis in Rat Abdominal Sepsis Model

Pires BBS, et al

group with saline peritoneal lavage. This fact permited to establish a correlation of a possible antibacterial activity with the treatment with coconut water.

\section{CONCLUSION}

The treatment of abdominal sepsis with peritoneal lavage using coconut water positively afluenced the healing of colon anastomosis in rats. It favored the bursting pressure, the reduction of inflammatory process, and bacterial colonization.

\section{REFERENCES}

1. Brocco MC, Gomez RS, Paulo DN, Almeida CE, Baptista JF. Histological features of peritoneal lavage with ropivacaine in rats with fecal peritonitis. Acta Cir Bras. 2012 ;27(2):193-9.

2. Radé F, Bretagnol F, Auguste $\mathrm{M}$, Di Guisto $\mathrm{C}$, Huten $\mathrm{N}$ and Calan L. Determinants of outcome following laparoscopic peritoneal lavage for perforated diverticulitis. Br J Surg. 2014;101 (12): 1602-16

3. Smith J, Garrison R, Matheson P, Harbrecht B, Benns M, Franklin G, Miller K, Bozeman M. e Richardson J. Adjunctive treatment of abdominal catastrophes and sepsis with direct peritoneal resuscitation: Indications for use in acute care surgery. J Trauma Acute Care Surg. 2014;77(3):393-9.

4. Toorenvliet B, Swank H, Schoones J, Hamming J and Bemelman E. Laparoscopic peritoneal lavage for perforated colonic diverticulitis: a systematic review. The Association of Coloproctology of Great Britain and Ireland. Colorec Dis. 2009; 12(9): 8627.

5. Inan $A$, Sen $M$, Sürgit $O$, Ergin $M$, Bozer $M$. Effects of the histamine $\mathrm{H} 2$ receptor antagonist famotidine on the healing of colonic anastomosis in rats. Clinics. 2009;64(6):567-70

6. Veneziano SG, Ramalho FS, Campos AD, Rocha JJR. Effect of thalidomide on the healing of colonic anastomosis in rats. Acta Cir Bras. 2008;23 (suppl.1):17-237.

7. Torres OJM, Macedo EL, Melo TCM, Costa JVG, Nunes PMS, Viana RMM, Dietz UA. Peritonite fecal em ratos: eficácia da lavagem da cavidade peritoneal com solução de cloreto de sódio a 0,9\%. Acta Cir. Bras. 1999;14(2) (http://dx.doi.org/10.1590/S010286501999000200003) 
Effect of Peritoneal Lavage with Coconut Water in Healing of Colon Anastomosis in Rat Abdominal Sepsis Model

Pires BBS, et al

8. Pummer S, Hell P, Maleck W, Petroianu G. Influence of Coconut Water on Hemostasis. Am J Emerg Med. 2001;19(4):287-9.

9. Campbell-Falck D, Thomas T, Falck T, TutuoN, Clem K. The Intravenous Use of Coconut Water. American Journal os Emergency Medicine. 2000;18(1):108-11.

10. Vigliar R, Sdepanian VL, Fagundes-Neto U. Biochemical profile of coconut water from coconut palms planted in an inland region. J Pediatr. 2006;82:308-12.

11. Carneiro, BGMC; Petroianu A, Rodrigues FHOC and Rocha RF. Estudo comparativo entre diversos tipos de tratamento para peritonite fecal em rato. Rev Col Bras Cir. 2002;29(1):43-8.

12. Morris AM, Kin C. Surgery for diverticulitis in the 21st century: recente evidence. Minerva Gastroenterol Dietol. 2017;63(2):158-62.

13. Tetikcok R, Kayaoglu HA, Ozsoy Z, Yenidogan E, Ozkan N, Celik A, Sahin S, Ersoy OF. The Effect of peritoneal prednisolone lavage in bacterial peritonitis: an experimental study. Wounds. 2016;28(10):354-9.

14. César JMS, Petroianu A, Vasconcelos LS, Cardoso VN, Mota LG, Barbosa AJA, Soares DV, Oliveira AL. Preliminary study of coconut water for graft tissues preservation in transplantation. Rev Col Bras Cir. 2015; 42(1): 43-8.

15. Yong JW, Ge L, Ng YF, Tan SN. The chemical composition and biological properties of coconut (Cocos nucifera L.) water. Molecules. 20099;14(12):5144-64.

16. Storch M, Perry LC, Davidson JM, Ward JJ. A 28-day study of the effect of Coated VICRYL* Plus Antibacterial Suture (coated polyglactin 910 suture with triclosan) on wound healing in guinea pig linear incisional skin wounds. Surg Infect (Larchmt). 2002;3 Suppl 1:S89-98. 